Петров O.B. ${ }^{1}$

\title{
Российско-турецкие
}

\section{экономические отношения}

\section{на современном этапе развития}

\begin{abstract}
Рассмотрены актуальные проблемы экономического положения Турции и российско-турецких торговых отношений с целью выявления положительных и отрицательных факторов, оказывающих влияние на торговлю между двумя странами. Сделана попытка ответить на следующие вопросы на основе официальных статистических данных России и Турции: в каком направлении развиваются торговые отношения между Россией и Турцией? С какими рисками столкнутся российские предприниматели при сотрудничестве с турецкими компаниями? Возможно ли в перспективе вступление Турции в Евразийский экономический союз?
\end{abstract}

Ключевые слова: Турция, Россия, торговля, экспортно-импортные отношения, российско-туреикие отночения, экономические риски.

\section{Введение}

Согласно данным официального сайта Министерства иностранных дел РФ датой установления дипломатических отношений между Россией и Турцией считается 3 июня 1920 г. [1]. К этому моменту, после поражения в Первой мировой войне, Турция уже не имела былого величия «Вечного государства» - Османской империи, а Россия вследствие Гражданской войны сменила форму государственного правления и также перестала именоваться империей.

Торговые отношения являются вектором развития взаимоотношений стран. Проблема российско-турецких экономических отношений приобретает особую актуальность с учетом быстро меняющихся обстоятельств и не всегда последовательных взаимных действий в рамках сотрудничества в экономической сфере.

1 Петров Олег Вячеславович - заместитель исполнительного директора Aссоииации содействия участникам внешнеэкономической деятельности. E-mail: <pov@rusta.ru>. 
C XVIII в. отношения России и Турции складывались по-разному и достаточно противоречиво. Невозможно не заметить, что они сопровождались многочисленными военными конфликтами. В своих мемуарах начальник внешней разведки службы безопасности Германии (VI отдел PCXA) Вальтер Шелленберг, говоря о заключении между Турцией и Германией 5 июня 1941 г. договора о дружбе, высказал предположение о причинах такого шага со стороны Турции: «так как гигантская Россия всегда была для своего южного соседа источником постоянной опасности, Турция могла быть заинтересована только в ослаблении России» [2].

Последний раз отношения между нашими странами ухудшались в 2015 г. в связи со сбитым ВВС Турции фронтовым бомбардировщиком Су-24M ВКС РФ, входившим в российскую авиационную группу в Сирии [3].

Для России такие действия Турции стали неожиданностью, о чем Президент РФ В.В. Путин заявил на пресс-конференции 17 декабря 2015 г. [4].

В настоящее время отношения между двумя странами характеризуются как положительные, и это делает Турцию одним из ключевых партнеров России. Принимая во внимание то, что в последнее время наша страна активно развивает несырьевой экспорт, появляется необходимость в изучении потребностей турецкой экономики и ее открытости для российского экспорта. В связи с этим возникают следующие вопросы: в каком направлении развиваются торговые отношения между Россией и Турцией? С какими рисками столкнутся российские предприниматели при ведении бизнеса с турецкими компаниями? Возможно ли в перспективе вступление Турции в Евразийский экономический союз? Для ответов на эти вопросы были использованы показатели экономики Турции на современном этапе ее развития и экспортно-импортных отношений с Россией, а также выявлены положительные и отрицательные факторы, оказывающие влияние на торговые отношения двух стран.

\section{Экономика Турции}

Согласно данным Всемирного Банка, население Турции на 2017 г. составляло 80,3 млн человек, площадь территории страны равна 783562 кв. м. По прогнозам Министерства развития Турции, к 2020 г. ее население должно вырасти до 82,4 млн человек [5].

Территория страны состоит из следующих земель, \%:

- посевные площади (36);

- луга (26);

- леса (26);

- непродовольственные площади (12) [6]. 
В Турции развивается как сельское хозяйство, так и промышленность, что делает ее индустриально-аграрной страной. Сельское хозяйство Турции можно охарактеризовать к следующим образом:

- вследствие существующей формы рельефа посевная почва небольшая, фрагментированная и разбросанная;

- самой важной проблемой сельского хозяйства внутреннего региона является орошение;

- сельскохозяйственная деятельность еще не защищена от природных воздействий;

- ввиду нестабильности климата крестьяне заняты в нескольких видах сельскохозяйственной деятельности (фермерство, скотоводство, пчеловодство, производство фруктов и овощей и т.д.) [8].

Промышленная деятельность распределена по всей территории страны неравномерно. Большинство промышленных объектов сосредоточены в западной части страны и на побережье. Наиболее развитым промышленным регионом является Мармара, а наименее развитым - Восточная Анатолия. На транспортировку негативно влияют формы рельефа, непроходимые горы большой протяженности, глубокие долины, континентальный климат во внутренних регионах страны, недостаточность капитала и оборудования.

Турция экспортирует следующие продукты:

- готовую одежду;

- автомобили, товары длительного пользования, ковры, мебель;

- сельскохозяйственные продукты (хлопок, табак, орехи, инжир, виноград, цитрусовые и разные овощи);

- минералы бора, хром, медь, цинк, свинец, соль;

- живые животные и продукты животного происхождения.

Структура импорта Турции состоит из следующих позиций:

- сырая нефть, фармацевтические препараты, удобрения, бумага и химические продукты;

- электроника и оптические приборы;

- машины и оборудование;

- $\quad$ тропические продукты (кофе, какао, каучук и специи) ${ }^{1}$.

По состоянию на 2017 г. по ВВП на душу населения по паритету покупательной способности (ППС) Турция занимала 13-е место среди всех стран мира. В 2017 г. экономический рост в Турции ускорился до 7,4\% против 3,2\% в 2016 г. [7]. Опрошенные эксперты The Wall Street Journal в среднем ожи-

1 Более подробная информаиия об экспорте и импорте Туриии будет приведена далее при рассмотрении экспортно-импортных отночений с Россией. 
дали несколько меньший прирост ВПП - 7\%. Вместе с этим растет общий экспорт и импорт. Совокупный объем экспорта составил 157 млрд долл. Объем импорта также вырос до 233,8 млрд долл., из которых 48,3 млрд долл. приходится на машины и оборудование. Таким образом, наблюдается дефицит торгового баланса, чему способствует в числе прочих факторов падение стоимости турецкой лиры по отношению к доллару и евро. В структуре импорта значительно преобладают промежуточные товары, предназначенные для дальнейшего производства товаров и услуг.

В социальной сфере наблюдаются трудности с обеспечением населения работой. В феврале 2018 г. уровень безработицы составил 10,6\%. Среди молодежи с учетом сезонных колебаний этот показатель превышает $18 \%$. Опять-таки с учетом сезонных колебаний в сельском хозяйстве заняты 5,5 млн человек, в промышленности - 5,6 млн, в строительстве - 2,2 млн, в сфере услуг - 15,5 млн человек. Хотя уровень безработицы остается высоким, в последние годы наблюдается рост занятости населения в промышленности.

Несмотря на приведенные выше показатели растущей экономики, ускоряющаяся инфляция заставляет инвесторов насторожиться. По состоянию на май 2018 г. средний показатель инфляции составил 12,1\%, прогнозный показатель инфляции на 2018 г. рассчитанный Министерством развития республики, составляет 7,0\%. С 2011 г., средний уровень инфляции только повышался. В 2017 г. в рейтинге стран мира по уровню инфляции Турция занимала 19-ю позицию. Весной 2018 г. колумнист турецкого издания Hürriyet Эрдал Саглам обратил внимание, что «цены производителей колеблются на более высоком уровне, чем потребительские цены. А они являются основой будущего роста потребительских цен до тех пор, пока спрос будет значительным. Внутренний индекс цен производителей в феврале изменился на $2,68 \%$ по сравнению с предыдущим месяцем. Он вырос на 3,69\% по сравнению с декабрем 2017 г. и 13,71\% по сравнению с февралем 2017 г. Эти цифры указывают на потенциальный рост потребительских цен в ближайшем будущем» [8]. Центральным банком Турции 7 июня 2018 г. было принято решение повысить ключевую ставку с 16,5 до 17,75\%. До этого ключевая ставка была повышена в мае 2018 г. в ходе экстренного заседания Центрального банка Турции. Такая мера была предпринята в целях сдерживания инфляции и стабилизации курса национальной валюты.

Курс лиры к доллару США снизился примерно на 20\% с начала 2018 г. изза беспокойства инвесторов по поводу «перегрева» турецкой экономики, роста дефицита счета текущих операций и высокой нарастающей инфляции. Кроме того, аналитики предупреждают, что зависимость компаний от иностранного финансирования делает их уязвимыми перед укреплением доллара и повышением процентных ставок в США. Внешний долг турецких компаний равен 295 млрд долл., и его становится все труднее обслуживать [9]. Следует обратить внимание на следующий факт: на фоне ухуд- 
шающейся экономической ситуации с 2015 г. снижается размер входящих прямых иностранных инвестиций (ППИ) [9]. Для сравнения: в 2015 г. их объем составлял 18,0 млрд долл., а в 2017 г. - 10,9 млрд долл.

В целом приведенные сведения говорят о значительном росте экономических показателей Турции по сравнению с кризисами 2001 и 2008 гг., что позволяет аналитикам из Подсекретариата Казначейства и Института статистики Турции делать положительные прогнозы развития экономики до 2020 г. Прогнозы международных экспертов в конце 2017 г. также были оправданы в связи с ускорившимся экономическим ростом до $7,4 \%$, который произошел благодаря предоставлению государственных гарантий и кредитованию бизнеса. С 2013 г. международное рейтинговое агентство Standard \& Poor's стабильно оценивало кредитный рейтинг страны на уровне «ВB+» и «ВВ».

В мае 2018 г. Standard \& Poor's понизило кредитный рейтинг Турции с «ВВ» до уровня «ВВ-» в иностранной валюте и с «BВ+» до «ВВ» в местной. В релизе агентства говорится, что прогноз стабильный. Однако нетрудно заметить негативные изменения, связанные с ростом инфляции, ослаблением турецкой лиры к доллару США, оттоком иностранного капитала. Имеющийся дефицит бюджета и рефинансирование приводят к увеличению внешнего долга Турции. По мнению Президента Турции Реджепа Эрдогана, снижение процентной ставки позволит уменьшить инфляцию. Такое заявление отпугивает инвесторов, особенно на фоне того, что Р. Эрдоган планирует уменьшить независимость Центрального банка Турции. Это также противоречит традиционной экономической теории, согласно которой сокращение денежной массы в условиях начинающегося «перегрева» экономики через установление высоких процентных ставок должно сдерживать инвестиционную и хозяйственную активность бизнеса.

\section{Товарооборот между Россией и Турцией}

Несмотря на возникающие разногласия по внешнеполитическим вопросам, одним из ключевых партнеров Турции в сфере экономики является Россия. Это вызвано как экономической выгодой и географическим положением, так и политическими факторами. На заседании Совета сотрудничества высшего уровня между Россией и Турцией 3 апреля 2018 г. В.В. Путин заявил, что по итогам 2017 г. товарооборот между двумя странами увеличился на внушительные 40\%, до 22 млрд долл. [10].

Для оценки существующего товарооборота между Турцией и Россией следует обратиться к статистическим данным, формируемым государственными органами двух стран. По мнению автора, наиболее достоверными являются сведения Федеральной таможенной службы РФ (ФТС России) и Института статистики Турецкой Республики. 
Согласно таможенной статистике ФТС России, по результатам торговли в 2017 г. экспорт Российской Федерации в Турецкую Республику составил почти 18,7 млрд долл., что превышает показатели 2016 г. на 5 млрд долл. Объемы импорта значительно ниже и составляют 3,4 млрд долл. Таким образом, товарооборот между Турцией и Россией имеет для последней положительное сальдо.

Для обеспечения предметности приведенных цифр ниже помещена таблица, иллюстрирующая экспорт и импорт России во взаимоотношениях с Турцией по товарным группам. Обращаем внимание, что в правой части таблицы приведены данные UN Comtrade Database.

С первого взгляда кажется, что товарооборот диверсифицирован и затрагивает большой перечень товарных номенклатур внешнеэкономической деятельности. Однако следует обратить внимание на то, что в структуре экспорта России преобладает сырье, включая группы «Топливо минеральное, нефть и продукты их перегонки; битуминозные вещества; воски минеральные» и «Черные металлы». Только две названные группы составили в 2017 г. 77\% всего экспорта нашей страны в Турцию. Впрочем, экспорт Турции выделяется другими товарными группами, в которых Россия имеет малую долю. Прежде всего это «Съедобные фрукты и орехи; кожура цитрусовых плодов или корки дынь», разные предметы одежды, обувь и «Средства наземного транспорта, кроме железнодорожного или трамвайного подвижного состава, и их части и принадлежности». Хотя здесь особо выделены только эти товарные группы, следует иметь в виду, что в приведенной таблице имеются и иные готовые товары, по которым экспорт Турции превосходит российский более чем на 50\%. В причинах приведенных показателей лежат потребности государства в определенных товарах, а также экономическая целесообразность в импорте или экспорте.

Турция со своей стороны также ведет статистику внешней торговли, которая ниже сравнивается с российской статистикой. Так, институт статистики Турции сообщает, что в 2017 г. совокупный объем экспорта в Россию составил 2,7 млрд долл. При этом Россия занимает только 17-е место в списке государств, с которыми Турция имеет экспортные отношения, и, таким образом, имеет долю 1,7\% во всем объеме экспорта Турции. Заметим, что указанная цифра отличается от цифры, приведенной ФТС России, на 0,6 млрд долл. Обратная ситуация наблюдается в импорте Турции. Тот же источник заявляет, что импорт России в Турцию равен 19,5 млрд долл., что делает Россию третьей по величине страной-импортером в Турции после Китая и Германии. Объем импорта России в общем объеме импорта иностранных государств в Турцию составляет 8,3\%.

К сожалению, Институт статистики Турции не дает информацию об экспортно-импортных отношениях с конкретными странами, в том числе с Россией, по группам товаров. В связи с этим следует обратиться к данным сервиса TradeMap, в котором отражена информация UN Comtrade Database. Именно 


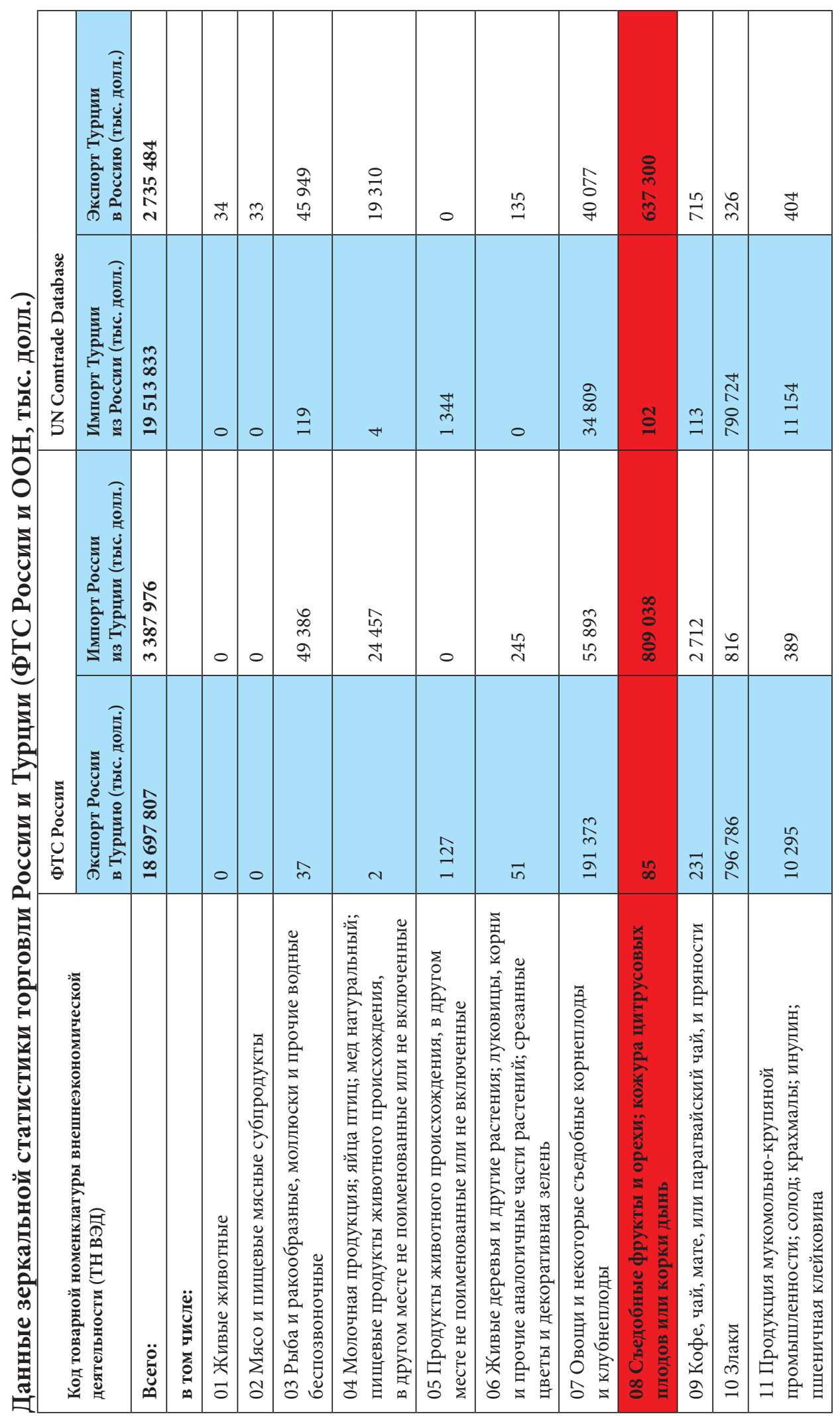




\begin{tabular}{|c|c|c|c|c|c|c|c|c|c|c|c|c|}
\hline $\begin{array}{l}\stackrel{\sim}{\mathbb{N}} \\
\infty \\
\sim\end{array}$ & $\tilde{m}$ & $\stackrel{\infty}{\rightarrow}$ & in & $\begin{array}{l}n \\
\vdots \\
0 \\
0 \\
0\end{array}$ & $\begin{array}{l}\text { Î } \\
\text { d } \\
\end{array}$ & $\begin{array}{l}8 \\
\infty \\
\infty \\
m\end{array}$ & $\begin{array}{l}\stackrel{a}{a} \\
\stackrel{\infty}{n}\end{array}$ & $\begin{array}{l}0 \\
\hat{0} \\
0 \\
0\end{array}$ & 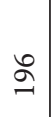 & i̊ & 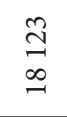 & $\begin{array}{l}\widehat{D} \\
0 \\
\not \\
\not\end{array}$ \\
\hline $\begin{array}{l}\text { 今े } \\
\text { ते }\end{array}$ & 0 & 0 & $\begin{array}{l}\text { ळొ } \\
\infty \\
\infty\end{array}$ & $\begin{array}{l}\vec{a} \\
\overrightarrow{0} \\
\dot{m}\end{array}$ & $\stackrel{\infty}{\infty}$ & $\stackrel{m}{F}$ & ఃे & $\begin{array}{l}0 \\
0 \\
\simeq \\
\simeq\end{array}$ & 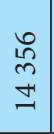 & $\begin{array}{l}\text { ले } \\
\text { స్ }\end{array}$ & 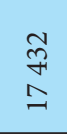 & ณू \\
\hline $\begin{array}{l}\text { वे } \\
\text { \&े }\end{array}$ & $\stackrel{2}{=}$ & - & S & $\begin{array}{l}\stackrel{\alpha}{0} \\
\Xi \\
\exists\end{array}$ & $\begin{array}{c}\infty \\
\text { in } \\
\infty \\
m\end{array}$ & 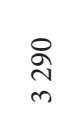 & 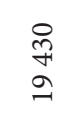 & $\begin{array}{l}\infty \\
\infty \\
\infty\end{array}$ & $\hat{\sigma}$ & : & $\begin{array}{l}\stackrel{+}{N} \\
\stackrel{\Delta}{N}\end{array}$ & $\begin{array}{l}\text { 点 } \\
\text { in }\end{array}$ \\
\hline $\begin{array}{l}\text { fै } \\
\text { త్ }\end{array}$ & 0 & $\underset{\sim}{\stackrel{\infty}{\rightarrow}}$ & 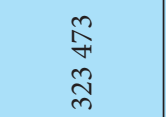 & 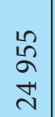 & के & ठे & $\underset{\sim}{\mathbb{N}}$ & $\begin{array}{l}\vec{y} \\
\text { ă }\end{array}$ & $\begin{array}{l}\overrightarrow{0} \\
\stackrel{0}{\circ}\end{array}$ & 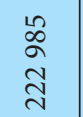 & 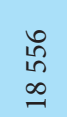 & $\stackrel{\dddot{\gamma}}{2}$ \\
\hline 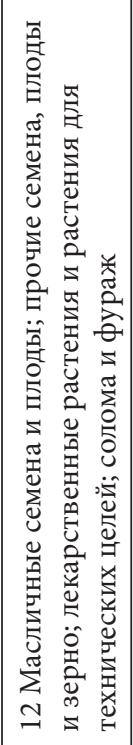 & 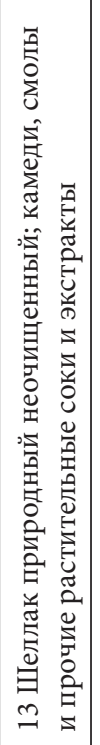 & 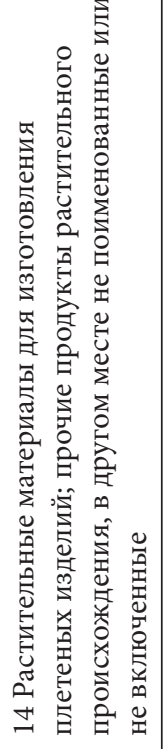 & 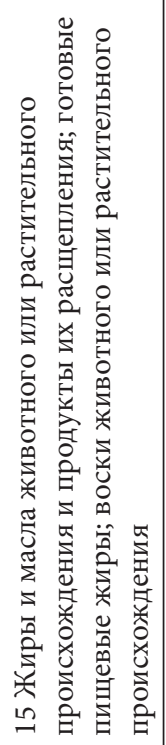 & 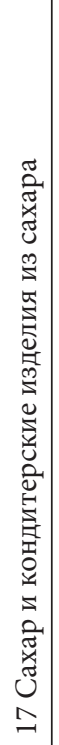 & 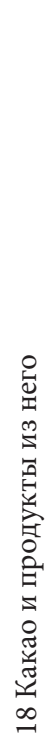 & 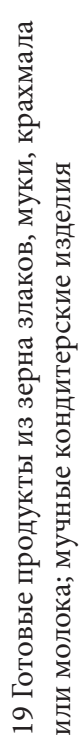 & 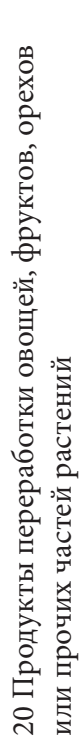 & 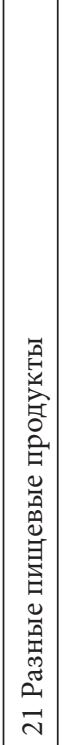 & 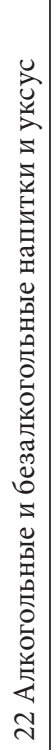 & 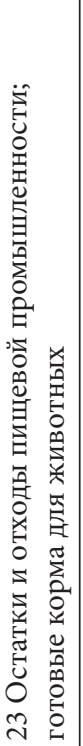 & 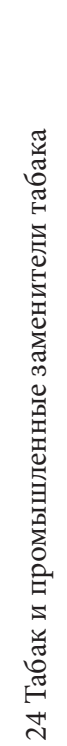 & 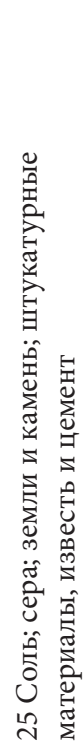 \\
\hline
\end{tabular}




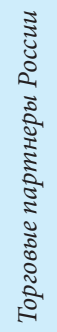

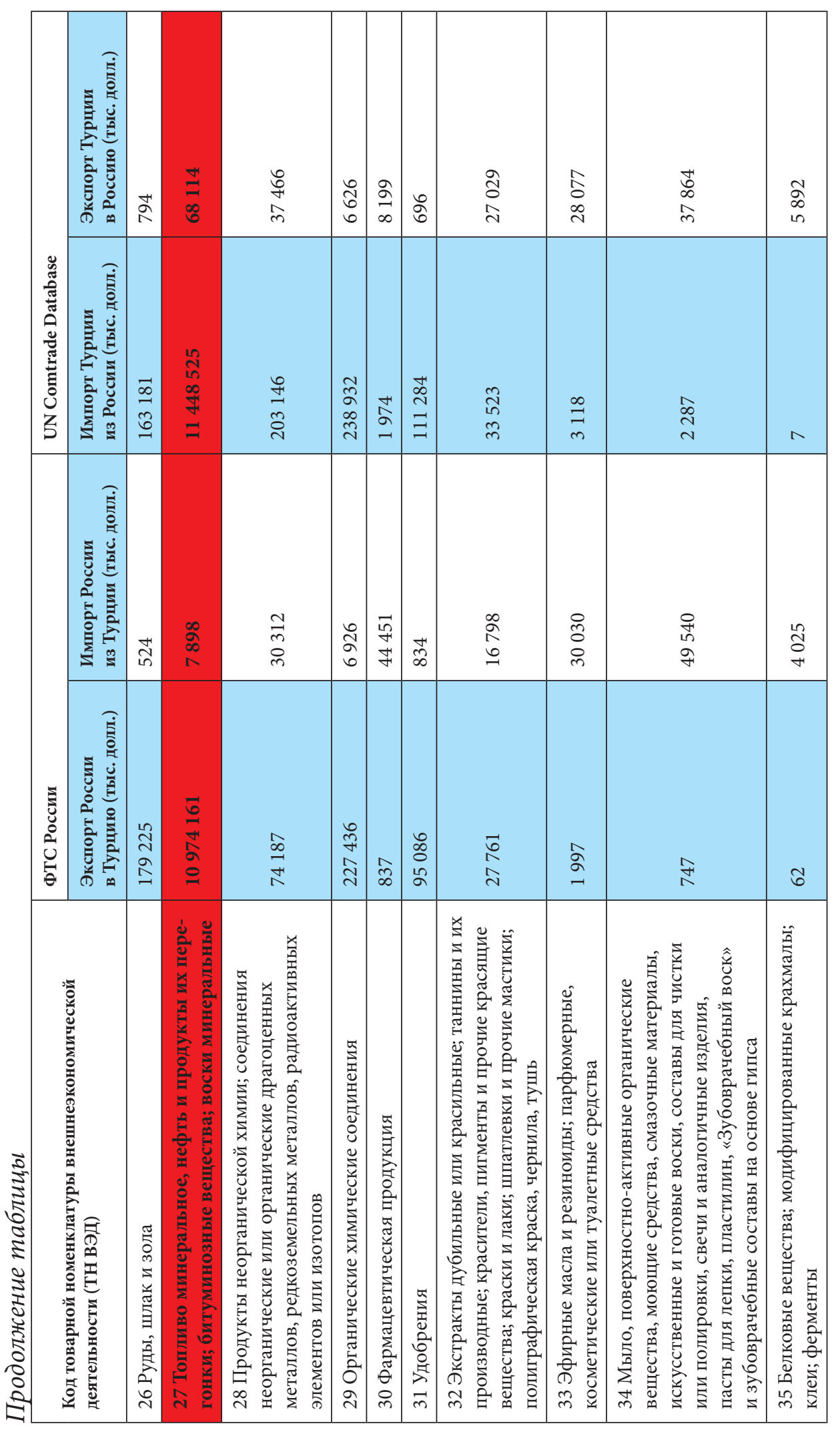




\begin{tabular}{|c|c|c|c|c|c|c|c|c|c|c|c|c|}
\hline 0 & 0 & 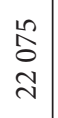 & $\begin{array}{l}\vec{a} \\
\hat{\sigma} \\
\stackrel{\Xi}{=}\end{array}$ & 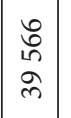 & $\stackrel{2}{8}$ & $\begin{array}{l}\infty \\
0 \\
0 \\
=\end{array}$ & $\begin{array}{l}\stackrel{テ}{\exists} \\
\vec{m}\end{array}$ & 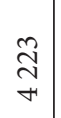 & 2 & 0 & $\begin{array}{l}\text { సे } \\
\infty \\
\text { I }\end{array}$ & 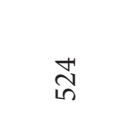 \\
\hline$\stackrel{2}{\sim}$ & $\stackrel{\sim}{~}$ & $\begin{array}{l}\vec{D} \\
\infty \\
m\end{array}$ & $\begin{array}{l}\infty \\
2 \\
\stackrel{2}{=}\end{array}$ & $\begin{array}{l}\overrightarrow{\widehat{N}} \\
\vec{\infty}\end{array}$ & $\begin{array}{l}\vec{\infty} \\
\underset{n}{N}\end{array}$ & త్ & 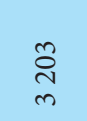 & 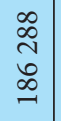 & 0 & $\begin{array}{l}\text { Oి } \\
\text { in }\end{array}$ & $\begin{array}{l}\text { ฟे } \\
\text { ิㅡㄴ }\end{array}$ & $\infty$ \\
\hline 0 & 0 & $\begin{array}{l}\text { मे } \\
\text { ఫे } \\
\text { নे }\end{array}$ & 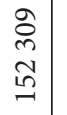 & 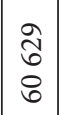 & $\underset{\sim}{\vec{N}}$ & $\begin{array}{l}\overrightarrow{\widetilde{N}} \\
\stackrel{0}{\sim}\end{array}$ & 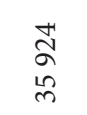 & $\begin{array}{l}1 \\
\text { o } \\
m\end{array}$ & 0 & 0 & $\begin{array}{l}\tilde{m} \\
\stackrel{m}{n}\end{array}$ & ลे \\
\hline 0 & 0 & $\stackrel{m}{\stackrel{n}{a}}$ & 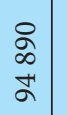 & $\begin{array}{l}\approx \\
\infty \\
\sigma\end{array}$ & $\frac{m}{m}$ & ఫे & in & $\begin{array}{l}9 \\
\infty \\
\infty \\
\alpha\end{array}$ & 0 & $\stackrel{\infty}{\stackrel{\infty}{\sigma}}$ & $\begin{array}{l}\text { 옹 } \\
\exists \\
\exists\end{array}$ & $\infty$ \\
\hline 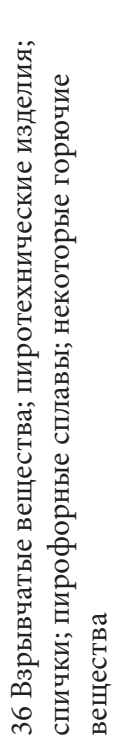 & 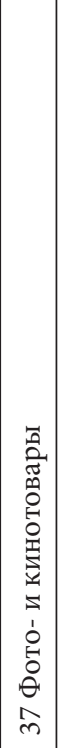 & 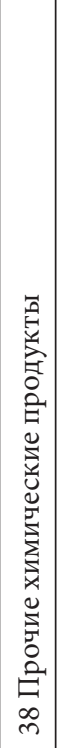 & 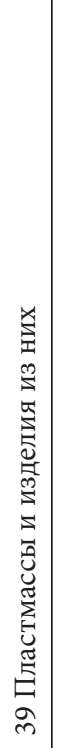 & 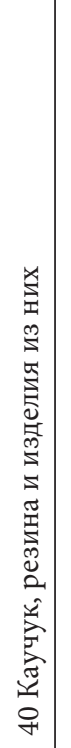 & 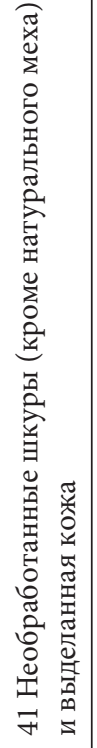 & 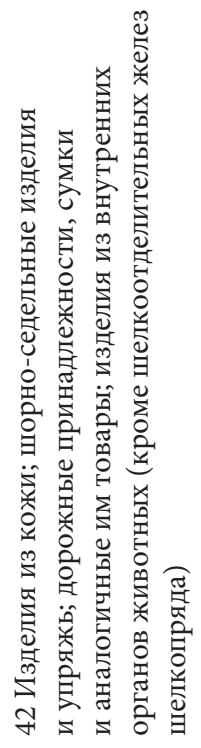 & 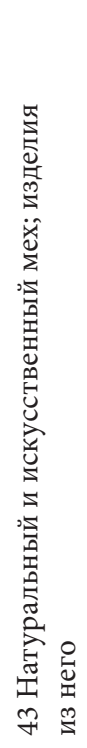 & 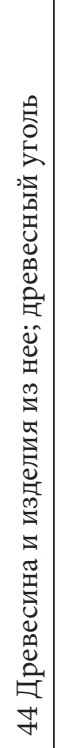 & 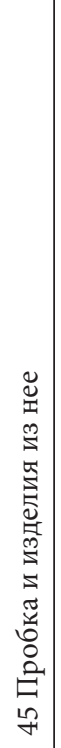 & 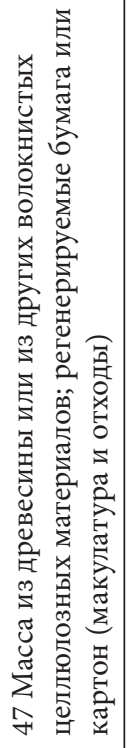 & 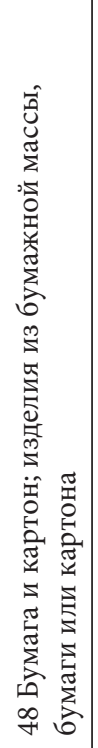 & 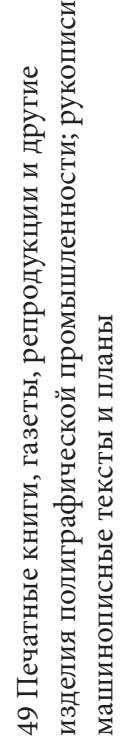 \\
\hline
\end{tabular}




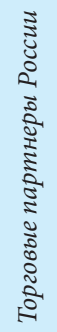

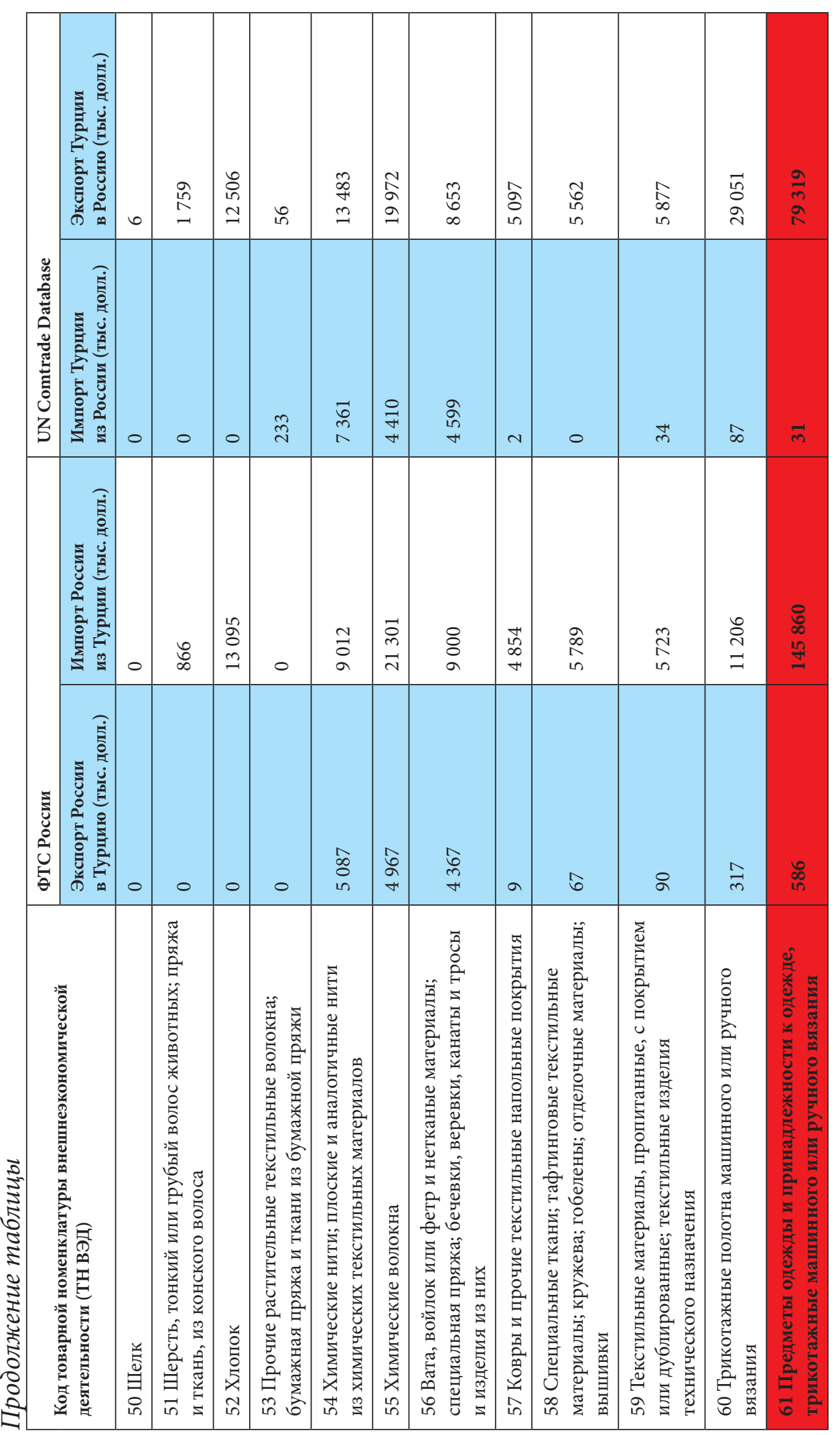




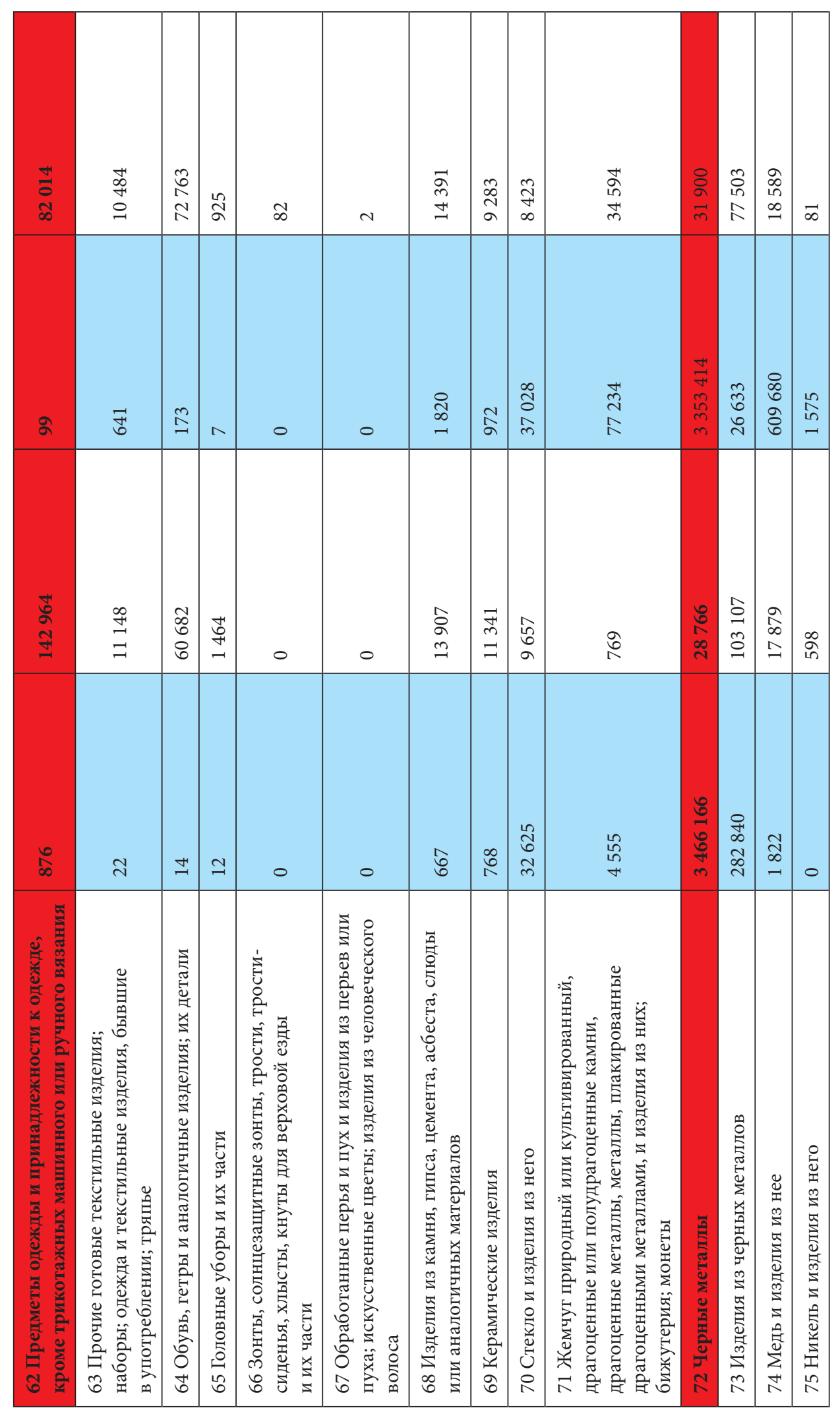

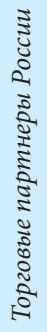




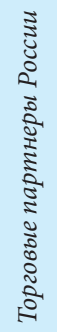

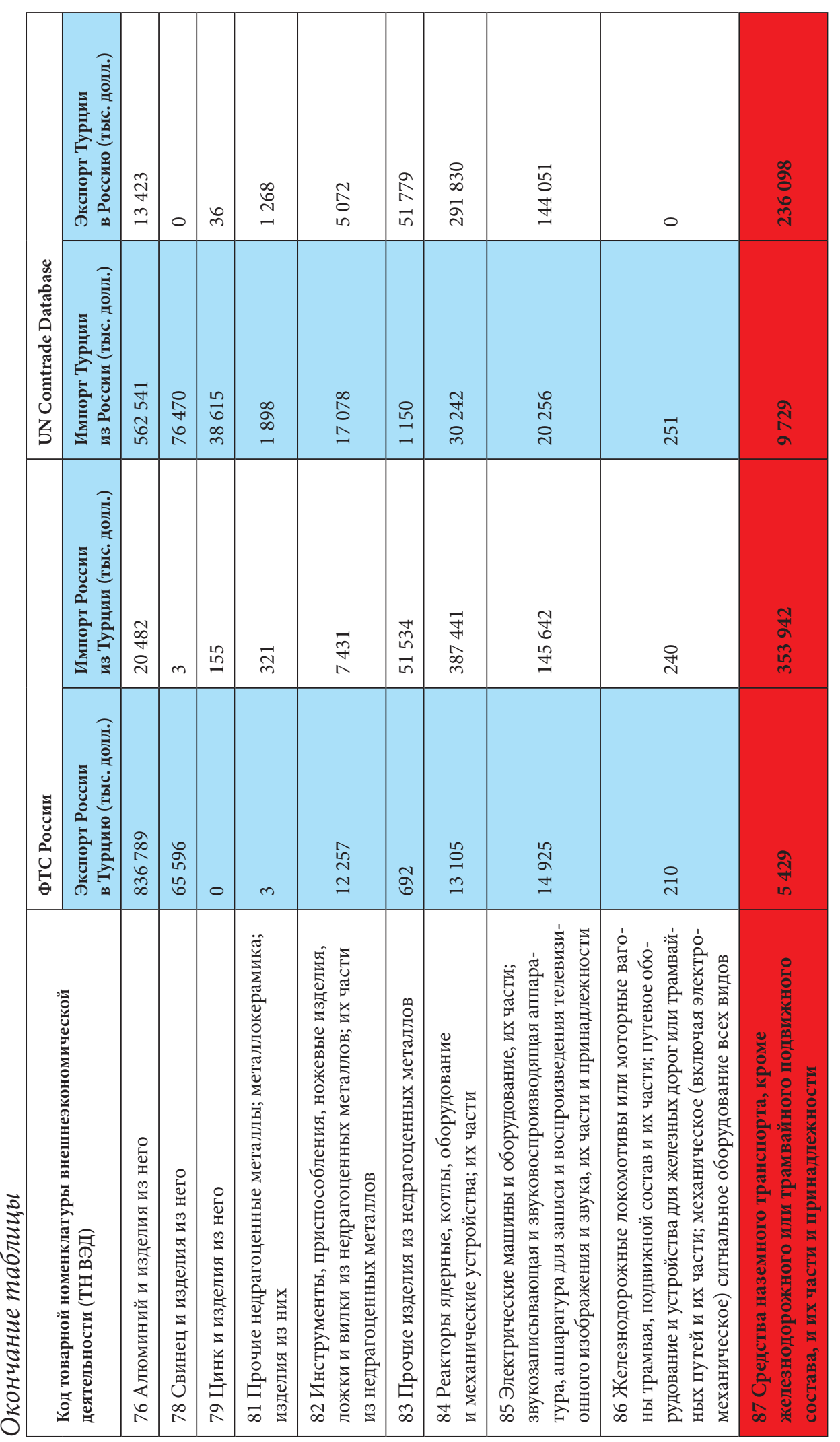




\begin{tabular}{|c|c|c|c|c|c|c|c|c|c|c|}
\hline $\begin{array}{l}\infty \\
\stackrel{2}{7} \\
\text { f }\end{array}$ & 8 & $\begin{array}{l}\text { m) } \\
\text { = } \\
=\end{array}$ & हैరे & $\stackrel{m}{\infty}$ & $\begin{array}{l}\stackrel{P}{+} \\
\text { in }\end{array}$ & $\begin{array}{l}\stackrel{g}{0} \\
\vec{m}\end{array}$ & $\begin{array}{c}\text { oD } \\
\stackrel{+}{+}\end{array}$ & $\begin{array}{l}尺 \\
\hat{N} \\
0 \\
=\end{array}$ & $N$ & $\hat{\sigma}$ \\
\hline తి & $\begin{array}{l}\text { ลे } \\
\text { in }\end{array}$ & $\underset{\sim}{\stackrel{m}{\sim}}$ & 0 & - & in & $\underset{\widetilde{\sigma}}{\tilde{\sigma}}$ & $\tilde{6}$ & $\begin{array}{l}\stackrel{n}{\tilde{m}} \\
\tilde{n}\end{array}$ & in & - \\
\hline 0 & 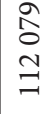 & ஓু & 0 & 0 & 0 & $\begin{array}{l}\tilde{N} \\
\text { in } \\
m\end{array}$ & $\stackrel{\stackrel{\leftrightarrow}{\omega}}{\stackrel{m}{n}}$ & $\begin{array}{l}\stackrel{\widetilde{\Xi}}{\Xi} \\
=\end{array}$ & 0 & 0 \\
\hline 0 & 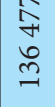 & ळે & 0 & 0 & 0 & లి & in & $\begin{array}{l}\mathbb{N} \\
\hat{O} \\
m\end{array}$ & 0 & 0 \\
\hline 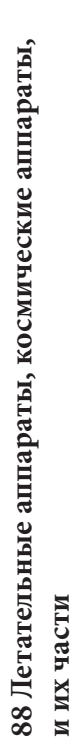 & 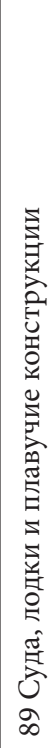 & 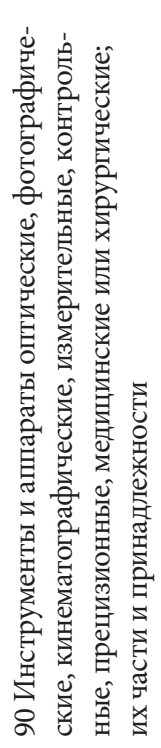 & 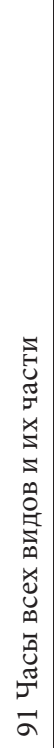 & 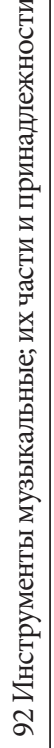 & 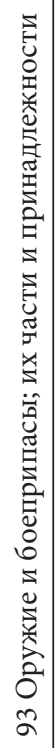 & 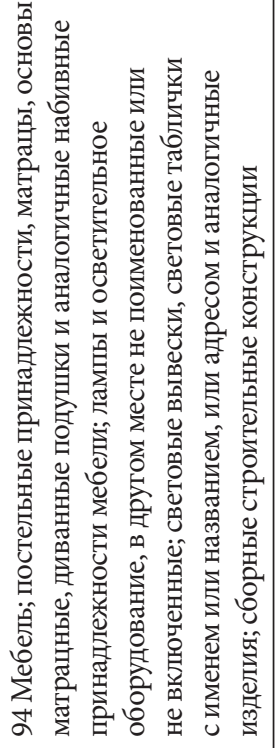 & 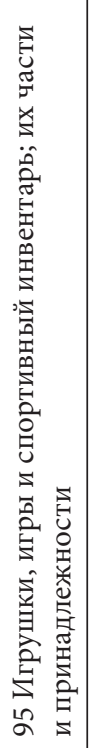 & 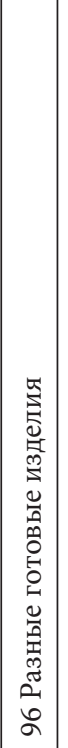 & 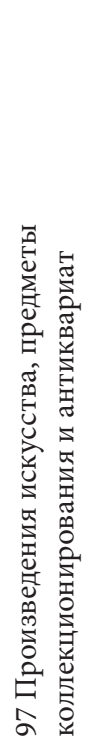 & 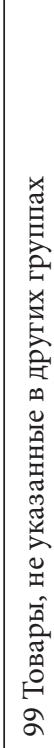 \\
\hline
\end{tabular}


этот сервис выбран потому, что он показывает совокупный объем экспорта и импорта Турции в размере 2735484 тыс. долл. и 19513833 тыс. долл. соответственно. Хотя эти показатели не идентичны информации Института статистики Турции, они наиболее близки к ней.

В приведенной таблице отчетливо видны расхождения по группам товаров. По некоторым товарным группам объем экспорта или импорта из выбранных двух источников может отличаться в несколько раз. Например, в статистике ФТС России не отражается группа 93 «Оружие и боеприпасы; их части и принадлежности». Согласно информации UN Comtrade Database, объем экспорта Турции в Россию по этой группе составил 5240 тыс. долл. против 55 тыс. долл. экспорта России в Турцию. Принимая во внимание военные конфликты в ближневосточном регионе, развитие военно-промышленного комплекса Турции не должно удивлять. Экспортерами турецкого оружия являются компании Akkurt, TISAŞ, MKEK. Это не только гражданские охотничьи и помповые ружья, но и армейское вооружение. Кроме того, Турция активно развивает свою программу судостроительства кораблей военного назначения MILGEM. Среди производителей прочей военной техники следует упомянуть компании Nurol Makina и Otokar. Активизация Турции в развитии собственного военно-промышленного комплекса связана со стремлением снизить зависимость от иностранных экспортеров, в том числе стран НАТО, членом которого она является. После наступления турецких войск в сирийском Африне в начале 2018 г. депутаты Бундестага призвали власти Германии отказаться от плановой модернизации танков «Леопард» ВС Турции, а также ограничить военные поставки [11].

Показательным также является пример с товарной группой 91 «Часы всех видов и их части». Если ФТС России не показывает эту информацию, то, согласно UN Comtrade Database, экспорт часов из Турции в Россию в 2017 г. составил 659 тыс. долл.

Одна из причин указанного серьезного расхождения может заключаться в декларировании одних и тех же товаров по разным, но схожим кодам ТН ВЭД для обхода торговых ограничений. Вместе с тем это не отвечает на все вопросы, возникающие в связи с расхождениями, потому что при допущении, что таможенные органы проводят проверку содержимого груза, сложно исказить код ТН ВЭД на уровне двух знаков. Если причины такого расхождения все же связаны с противоправными действиями участников внешнеэкономической деятельности, этот факт должен привести к проведению расследования таможенными службами. Тем не менее структура товарооборота между Россией и Турцией в целом отражается верно. Россия входит в тройку крупных импортеров Турции в основном за счет сырья. Вместе с тем следует заметить, что даже если исключить из экспорта России товарные группы 27 (топливо) и 72 (черный металл), то Россия остается в двадцатке стран-импортеров Турции. 


\section{Соглашения между Российской Федерацией и Турецкой Республикой}

Экономические отношения между Российской Федерацией и Турецкой Республикой складываются на основе двусторонних международных договоров и иных документов, как имеющих, так и не имеющих обязательную силу. В частности, к ним относятся:

Протокол между Правительством Российской Федерации и Правительством Турецкой Республики о сотрудничестве в нефтяной сфере от 6 августа 2009 г. (вступил в силу 11 января 2012 г.);

Соглашение между Правительством Российской Федерации и Правительством Турецкой Республики о культурном и научном сотрудничестве от 19 июля 1994 г. (вступило в силу 2 ноября 1994 г.);

Соглашение между Правительством Российской Федерации и Правительством Турецкой Республики об избежании двойного налогообложения в отношении налогов на доходы от 9 сентября 1993 г. (вступило в силу 29 ноября 1994 г.);

Договор об основах отношений Российской Федерации и Турецкой Республики от 25 мая 1992 г. (вступил в силу 19 июля 1994 г.);

Соглашение между Правительством Российской Федерации и Правительством Турецкой Республики о создании Смешанной межправительственной российско-турецкой комиссии по торгово-экономическому сотрудничеству от 14 мая 1992 г. (вступило в силу 26 октября 1992 г.);

Соглашение между Правительством Российской Федерации и Правительством Турецкой Республики по проекту газопровода «Турецкий поток» от 10 октября 2016 г. (вступило в силу 18 февраля 2017 г.);

Совместное заявление министра экономического развития Российской Федерации А.В. Улюкаева и министра экономики Турецкой Республики Н. Зейбекчи по продвижению торгово-экономического и инвестиционного сотрудничества между Российской Федерацией и Турецкой Республикой от 28 ноября 2014 г.;

Меморандум о взаимопонимании в сфере малого и среднего предпринимательства между Министерством экономического развития Российской Федерации и Государственной организацией по развитию и поддержке малого и среднего предпринимательства Турецкой Республики (КОСГЕБ) от 1 декабря 2014 г;;

Меморандум о взаимодействии Федеральной службы по ветеринарному и фитосанитарному надзору (Российская Федерация) и Министерства 
сельского хозяйства и по делам деревень Турецкой Республики в области обеспечения качества и безопасности зерна и продуктов его переработки от 12 мая 2010 г.;

Соглашение между Правительством Турецкой Республики и Правительством Российской Федерации о сотрудничестве и взаимной помощи в таможенных делах от 16 сентября 1997 г. (вступило в силу 23 ноября 1997 г.).

Это далеко не полный список официальных документов, заключенных между Российской Федерацией и Турецкой Республикой, однако он показывает, насколько разносторонне развиваются отношения между двумя государствами. В то же время без установления подобных отношений не была бы возможной плодотворная взаимная торговля.

Согласно Меморандуму в области применения процедуры «упрощенный таможенный коридор» Россия и Турция договорились проводить работу по увеличению количества пунктов пропуска, применяющих процедуру упрощенного таможенного коридора (УТК). В настоящее время к ним относятся таможенные посты Внуковской, Брянской, Калужской, Курской, Смоленской, Северо-Осетинской, Минераловодской, Ростовской, Краснодарской и Новороссийской таможен. Ускорение таможенного оформления товаров в этих пунктах возможно благодаря предварительному информированию о ввозимых грузах, налаженному информационному обмену между Россией и Турцией и взаимному признанию обоими государствами результатов таможенного контроля.

Процедуры упрощенного таможенного коридора применяются участниками внешнеэкономической деятельности на добровольной основе, но в случае его применения это дает приоритет в пунктах пропуска и местах основного таможенного оформления по сравнению с турецкими и российскими компаниями, не принимающими участие в УТК.

В 2013 г. состоялось торжественное открытие железнодорожно-портовой линии Кавказ - Самсун, работавшей до этого в тестовом режиме на основе Соглашения об организации смешанного международного железнодорожно-паромного сообщения через порты Кавказ и Самсун от 12 мая 2010 г. Само Соглашение не устанавливает прямых правил, регламентирующих перевозки, однако оно стало базой для принятия Правил перевозок грузов, вагонов и контейнеров в смешанном международном железнодорожно-паромном сообщении через порты Кавказ и Самсун от 31 июля 2010 г. В соответствии с этими Правилами перестановка вагонов колеи 1520 мм на тележки колеи 1435 мм и обратно, а также перегрузка грузов производятся в порту Самсун. Кроме того, в Правилах оговариваются порядок и сроки предъявления груза к перевозке, предметы и грузы, не допускаемые к перевозке, порядок заключения договоров перевозки и оформления накладных, случаи отказа в приеме вагона с грузом принимающей стороной, ответственность перевозчика и т.д. 
Важным фактором установления и развития торговых отношений двух стран также является определение и устранение барьеров. С этой целью в 2014 г. Министерство экономического развития РФ и Министерство экономики Турецкой Республики идентифицировали барьеры во взаимной торговле и договорились координировать взаимодействие министерств и ведомств, направленное на устранение барьеров. Сторонами были обозначены две сферы: транспортная и таможенная. Однако на фоне ухудшения отношений (после инцидента со сбитым российским самолетом) и введения взаимных санкций разрешения на двусторонние автомобильные перевозки были уменьшены в 4 раза: с 8 тыс. до 2 тыс. В 2017 г. этот барьер был преодолен за счет увеличения разрешений до 12 тыс., что соответствует уровню 2012 г. Среди прочих проблем российской стороной также указаны:

- ограничение на ввоз на территорию Турции топлива в штатных баках транспортных средств российских автоперевозчиков;

- приоритетный доступ турецких автоперевозчиков и автоперевозчиков третьих стран по отношению к российским при загрузке товарами, предназначенными для экспорта из Турецкой Республики в Российскую Федерацию, и др.

15-16 января 2018 г. в Санкт-Петербурге состоялись переговоры экспертов по рассмотрению проекта Соглашения между Правительством Российской Федерации и Правительством Турецкой Республики о международном автомобильном сообщении [12], поэтому в ближайшее время проблемы в транспортной сфере могут быть решены новым двусторонним соглашением.

В таможенной сфере турецкой стороной была заявлена проблема использования на российских таможенных постах разных индикативных цен на один и тот же товар, поступающий из Турции.

В отношении отдельных товаров Турцией введены следующие специальные меры:

- антидемпинговая пошлина в размере 0,5 долл. за 1 кг кабеля и стального троса с 14 июля 2016 г. по 14 июля 2021 г.;

- антидемпинговая пошлина в размере $8 \%$ в отношении прозрачного неармированного стекла производства ООО «Гардиан Стекло Ростов», ООО «Гардиан Стекло Рязань» и АО «Саратовстройстекло», а для остальных российских компаний $-10 \%$;

- антидемпинговая пошлина в размере 5,28\% в отношении крафтлайнера (бумага) производства АО «Группа «Илим», а для остальных российских компаний - 11,19\%;

- защитная пошлина в размере от 3,75 до 3,25 долл. (в зависимости от года) за 1 кг обоев и аналогичных настенных покрытий.

Следует заметить, что, несмотря на обозначенные транспортные, таможенные и торговые барьеры, по состоянию на момент написания настоящей 
статьи Турция и Россия не участвовали в торговых спорах друг к другу в рамках Всемирной торговой организации (ВТО).

В то же время, по нашему мнению, дальнейшее развитие экономических отношений между Россией и Турцией в рамках единой международной организации по типу Европейского экономического союза (ЕАЭС) невозможно. На протяжении длительного времени Турция намеревалась вступить в Европейский Союз; этот процесс идет по настоящее время. Хотя Президент Турецкой Республики Р. Эрдоган заявил в 2018 г., что вступление в Европейский Союз остается для страны стратегической целью, и для этой цели была проделана большая работа по демократизации общества, события, последовавшие после 2010 г. в ближневосточном регионе, свидетельствуют о развороте Турции от европейского Запада на мусульманский Восток. По этой же причине в ближайшем будущем Турция не станет перспективным направлением расширения ЕАЭС. Кроме того, приведение законодательства какой-либо страны в соответствие с положениями международной организации является длительным процессом. Например, в 2012 г. Центр ситуационного анализа Российской академии наук отмечал, что утверждена уже третья по счету программа по приведению турецкого законодательства в соответствие с законодательством ЕС [13].

Причиной частичного разворота исключительно от проевропейской политики может быть также объявленный бывшим министром иностранных дел Турции Ахмедом Давутоглу принцип внешней политики «ноль проблем с соседями». Напомним, что Ахмед Давутоглу является автором книги «Стратегическая глубина. Международное положение Турции», изданной в 2001 г. В ней излагается мысль о превращении Турции в мировую державу, в том числе снижение зависимости от Запада. Военные конфликты на Ближнем Востоке дают Турции возможность предстать перед арабскими странами прообразом современного государства, в котором сочетаются религиозное и демократичное общества.

Существует и иная причина, по которой Турция заинтересована в решении ближневосточного вопроса в свою пользу, и которая непосредственно связана с курдским вопросом. С давних времен Иракский Курдистан характеризовался как государство в государстве: в Курдистане свой президент, правительство, парламент. Е.М. Примаков задавался вопросом: не продвигается ли дело к созданию самостоятельного курдского государства? По словам бывшего президента Иракского Курдистана Масуда Барзани, задача курдов состоит в самоопределении, не выходя из Ирака [14]. Однако 25 сентября 2017 г. по результатам референдума Иракский Курдистан объявил о независимости. Для Турецкой Республики новообъявленное государство важно своим нефтеносным районом города Киркук. Как показала приведенная выше таблица торгового баланса, Турция зависима от импорта энергоносителей, и на Россию приходится существенная доля поставок нефти и нефтепродуктов. Поэтому Турецкая Республика заинтересована в реше- 
нии курдского вопроса с перспективой установления соглашений о поставках нефти на приемлемых для обеих сторон условиях.

Исследовательская группа НИУ ВШЭ, выпустившая в 2018 г. спецвыпуск «Евразийской панорамы», посвященной анализу направлений евразийской интеграции, также не называет Турцию одним из перспективных направлений расширения ЕАЭС. В то же время между ЕАЭС и соседом Турции Исламской Республикой Иран - заключено Временное соглашение о зоне свободной торговли, которое направлено на либерализацию торговли, снижение импортных таможенных пошлин во взаимной торговле [15].

Итак, между Россией и Турцией подписаны многочисленные соглашения, связанные как непосредственно с торговлей, так и с ускорением транспортировки и таможенного оформления товаров. Они, безусловно, способствуют развитию взаимных торговых отношений. Активно сотрудничая с Россией, Турция также не может не обращать внимания на проблемы с соседними государствами. Турция не считает, что альянс с западными международными организациями ограничивает ее в укреплении сотрудничества с Россией, Ираном или Китаем. По мнению Дюрана Бурханеттина, руководителя Фонда политических, экономических и социальных исследований (проправительственная организация в Турции), Турецкая Республика должна проводить сбалансированную политику между всеми государствами, так как политику Турции определяет не идеология, а национальные интересы [16].

По нашему мнению, вследствие переизбрания Р. Эрдогана Президентом Турции в торговой политике государства могут произойти изменения. Ранее существовавшее Министерство таможенной и торговой политики Турции объединилось с Министерством экономики и переименовано в Министерство торговли, которое с 9 июля 2018 г. возглавляет Рухсар Пекджан, известная тем, что долгое время занималась предпринимательской деятельностью в частном секторе. По случаю своего назначения на новый пост она заявила, что Турция должна приложить все усилия, чтобы сделать таможенные процедуры самыми правильными, самыми точными, самыми безошибочными и самыми быстрыми [17].

\section{Заключение}

В настоящее время в Турции налицо признаки нарастания экономического кризиса: курс турецкой лиры падает относительно доллара и евро, цены на товары повышаются, высокие темпы инфляции. На этом фоне происходит смена политической системы на президентскую республику и назначение нового состава правительства. Таким образом, Р. Эрдоган, став главой государства и правительства, приобрел безграничные полномочия. Заявления Президента Турецкой Республики о подчинении ему Центрального банка и намерение уменьшить процентную ставку для снижения уровня инфляции отпугивает иностранных инвесторов. С момента прихода к власти Партии справедливо- 
сти и развития под предводительством Р. Эрдогана Турция уже дважды проходила через экономический кризис. Исходя из этого факта, следует предположить, что глава государства все же прислушается к мнению экономистов и примет правильное решение ради снижения роста цен и возврата иностранных инвестиций. Более того, в 2023 г. в Турции планируется торжество по случаю 100-летия становления Турецкой Республики, и к этому времени Правительство Турции должно решить свои экономические затруднения.

Несмотря на возникающие политические разногласия и непоследовательность проводимой внешней политики, Россия и Турция остаются друг для друга ключевыми партнерами в экономической сфере. С учетом недавних взаимных торговых ограничений товарооборот между двумя странами в 2017 г. достиг 22 млрд долл. Подтверждением этому являются многочисленные международные соглашения и протоколы, устанавливающие участникам внешнеэкономической деятельности льготный режим торговых взаимоотношений. Россия является для Турции основным поставщиком природного газа и входит в число поставщиков сырой нефти; в Турции реализуются крупные российские проекты, среди которых следует назвать строительство газопровода «Турецкий поток» и атомной электростанции «Аккую». В свою очередь, Турция поставляет в Россию средства наземного транспорта, предметы одежды, фрукты. Кроме того, немаловажным является признание Турецкой Республики как экспортера строительных услуг.

Хотя интеграция России и Турции в рамках организации, подобной ЕАЭС, невозможна по ряду причин, и Турция остается конкурентом России в странах Средней Азии, главная проблема экономических отношений России и Турции не связана с отсутствием взаимовыгодных основ для сотрудничества. Препятствия могут возникать вследствие необдуманных и преждевременных действий сторон, имеющих исключительно политический характер. Изложенные в настоящей статье факты позволяют сделать практический вывод, что при организации сотрудничества с турецкими компаниями необходимо проявлять интерес к внутри- и внешнеполитическим событиям в регионе, который в настоящее время характеризуется нестабильностью.

\section{Источники}

[1] Официальный сайт Министерства иностранных дел РФ / Карта мира: Турция. URL: <http://www.mid.ru/ru/maps/tr/-/category/10557>.

[2] Шелленберг В. Мемуары [Лабиринт]. Минск: Родиола-плюс, 1998. URL: <https://www.e-reading.club/chapter.php/65135/44/Shellenberg_-_ Memuary_\%5BLabirint\%5D.html $>$.

[3] Официальный сайт Министерства обороны РФ / Выступление начальника Главного оперативного управления Генштаба ВС РФ гене- 
рал-лейтенанта Сергея Рудского по факту провокационных действий ВВС Турции. 25.11.2015. URL: <https://function.mil.ru/news_page/world/ more.htm?id=12066682@egNews>.

[4] На пресс-конференции Владимира Путина беспокоила Турция // Коммерсантъ. 18.12.2015. URL: <https://www.kommersant.ru/doc/2879507>.

[5] Hazine Müsteşarlığ1 / Türkiye ekonomisi. URL: <https://m.hazine.gov.tr/ File/Index?id=456b066c-2825-4481-8609-70c197313861 >.

[6] Coğrafya Sitesi / Türkiye’nin Ekonomik Coğrafyası. URL: <http://cografya. sitesi.web.tr/upload/kavram/10.pdf>.

[7] ВВП Турции вырос в 2017 году на 7,4\% // Вести. Экономика. 29.03.2018. URL: <http://www.vestifinance.ru/articles/99585>.

[8] Sağlam E. Şubat ayı enflasyonu ve faiz tartışması // Hürriyet. 06.03.2018. URL: $\quad<$ http://www.hurriyet.com.tr/yazarlar/erdal-saglam/subat-ayienflasyonu-ve-faiz-tartismasi-40762149>.

[9] Невельский А. Президент Турции Эрдоган напугал инвесторов // Ведомости. 24.05.2018. URL: <https://www.vedomosti.ru/economics/ articles/2018/05/24/770653-erdogan-napugal-investorov>.

[10] Путин: Товарооборот между Россией и Турцией в $\$ 22$ млрд - не предел. 03.04.2018. URL: <https://mir24.tv/news/16299182/putin-tovarooborot-mezhdu-rossiei-i-turciei-v-22-mlrd-ne-predel $>$.

[11] Ващенко В. Тревожный сигнал: смогут ли партнеры по НАТО оставить Турцию без оружия // Russia Today. 25.01.2018. URL: <https://russian. rt.com/world/article/473928-turciya-germaniya-oruzhiye-zapret>.

[12] Официальный сайт Росавтотранс / Россия и Турция разработают новое соглашение о международном автомобильном сообщении. 16.01.2018. URL: <https://rosavtotransport.ru/ru/press/news/2018/01/16/news_991.html>.

[13] Турция: новая роль в современном мире. М.: ЦСА РАН, 2012. С. 35.

[14] Примаков Е.М. Россия в современном мире. Прошлое, настоящее, будущее. М.: Центрполиграф, 2018. С. 251.

[15] Временное соглашение о зоне свободной торговли ЕАЭС - Иран / Ю.К. Кофнер [и др.] // Евразийская панорама. 2018. Июнь. № 3. С. 15.

[16] Burnahettin D. Turkey's foreign policy shaped by interests, not ideology // Daily Sabah. 11.04.2018. URL: <https://www.dailysabah.com/columns/ 
duran-burhanettin/2018/04/11/turkeys-foreign-policy-shaped-by-interests-not-ideology $>$.

[17] Официальный сайт Министерства торговли Турецкой Республики / Ticaret Bakanı Ruhsar Pekcan, görevi Tüfenkci'den devraldı. 11.07.2018. URL: <https://www.gtb.gov.tr/haberler/ticaret-bakani-ruhsar-pekcan-gorevi-tufenkciden-devraldi $>$.

\section{Petrov O. ${ }^{1}$}

\section{Russian-Turkish Economic Relations at the Present Stage of Development}

In this article, the author raises the urgent problems of Turkey's economic situation and Russian-Turkish trade relations. The aim of the work is to identify the positive and negative factors affecting trade relations between the two countries. The study is to answer the following questions: how the trade relations between Russia and Turkey are developing? What risks will Russian entrepreneurs face while cooperating with Turkish companies? Is Turkey likely to join the Eurasian Economic Union in the long term?

Key words: Turkey; Russia; trade; export-import relations; Russian-Turkish relations; economic risks.

Статья поступила в редакцию 25 июля 2018 г.

1 Petrov Oleg - deputy executive director, Association of assistance to participants in foreign trade activities.E-mail: <pov@rusta.ru>. 